\title{
AGRICULTURAL TRADE AND FINANCING THROUGH FDI
}

\author{
David Jovović ${ }^{1}$, Sandra Stojadinović Jovanović ${ }^{2}$ Boban Dašićc ${ }^{3}$
}

\begin{abstract}
Summary
The role and significance of agricultural products have been changing over time, both in the world trade and in global flows of foreign direct investments. The subject of analysis in this paper will be exactly those two areas, agricultural trade and agriculture financing through foreign direct investments. Foreign direct investments can contribute to agricultural performance in different ways, bringing a number of benefits and potential positive impacts. Therefore, the paper will analyse the flows and volumes of foreign direct investments in agriculture indicating whether there is potential for these benefits to be used. The aim of the paper is to investigate the agricultural trade flows and agricultural foreign direct investment flows and volumes of foreign direct investments used for agriculture financing in order to determine whether and to what extent they contribute to agricultural performance.
\end{abstract}

Key words: agriculture, foreign direct investment, trade, Serbia.

JEL: $F 10, F 21, Q 1$

\section{Introduction}

Agricultural products are extremely important in the world economy and the world trade. Although often neglected, agriculture represents a central part of development, the foundation that not only satisfies the need for food, but also provides the basis for industrial development and economic growth. It represents a significant factor of rural employment, important feature of economic growth, as well as a significant source of foreign currencies for many countries that export these products. In global trade, the role and significance of agricultural products have been changing over time, which will be the subject of analysis in the paper. The position and role of agriculture have also changed in global flows of foreign direct investments (FDI), which will also be the subject of research in this paper. These two areas - agricultural trade and agriculture financing

1 Ph.D., Associate Professor, Faculty of Agriculture, University of Pristina - Kosovska Mitrovica, 38219 Lesak, Serbia, Phone: + 381645999 421, E-mail: jovovicdavid@gmail.com

2 Ph.D., Assistant Professor, Faculty of Economics, University of Belgrade, Kamenicka 6, 11000 Belgrade, Serbia, Phone: + 381113021 102, E-mail: sandra@ekof.bg.ac.rs

3 Ph.D., High Economic School of Professional Studies Pec - Leposavic, 24 ${ }^{\text {th }}$ November nn, 38218 Leposavic, Serbia, Phone: + 381656265 211, E-mail: bobandasickg@gmail.com

EP 2014 (61) 2 (455-469) 
through foreign direct investments - will be subjected to a comparative analysis. Special attention will be paid to the issues related to Serbian agricultural trade and financing of Serbian agriculture through foreign direct investments. Foreign direct investments can contribute to agricultural performance in different ways, bringing a significant number of benefits and potential posit.ive impacts on agriculture. Therefore, the paper will analyse the flows and volume of foreign direct investments in agriculture indicating whether these potentials and resources are being used.

\section{Materials and methods}

The materials and data used in the paper come from several sources: Statistical Office of the Republic of Serbia, Central Bank of Serbia, Ministry of Agriculture, Forestry and Water Management of the Republic of Serbia, UNCTAD data and WTO data, as well as certain professional studies and findings from relevant domestic and foreign publications. The selected data have been systematized in the tabular spreadsheet and graphs enabling the presentation and interpretation of findings related to the research subject. The applied methods include analysis of statistical data and analytical and synthetic descriptive methods and comparisons, as well as inductive and deductive methods of reasoning. The paper indicates that agriculture and agricultural trade have great significance for the world economy and world trade and that they can be influenced considerably through direct investments from abroad. Consequently, the relevant issues are related to the volume of agricultural trade and volume of agricultural FDI. Apropos that, the paper is based on two hypotheses. The first hypothesis is based on the opinion that position and role of agriculture have changed both in the world trade flows and in the world FDI flows. The second hypothesis is based on the idea that, despite the importance of agriculture, FDIs in agriculture are very small, which indicates the lack of opportunities for using potential positive effects which FDI could bring to agriculture. Therefore, the goal of the paper is to investigate the comparative movement of agricultural trade flows and agricultural FDI flows and volumes of FDI by which agriculture is financed in order to determine whether and to what extent they contribute to agricultural performance.

\section{Trends in agricultural trade}

The importance of agriculture and agricultural trade has been changing over time under the influence of economic changes in countries' economies. Rapid industrialization and structural changes in countries' economies worldwide have led to decrease of significance of agriculture and its neglect. The share of secondary and tertiary sector in GDP has been increased and the share of agriculture has significantly dropped. Although the share of value added of agriculture in world GDP is not on the high level, agriculture, on the other hand, offers significant possibilities for employment, and it also has a very important role in export of many countries (Table 1). Agriculture accounts for 1/3 of total employment in the world, and in particular regions for more than $70 \%$ of total employment. Export of agricultural products has a significant place in export of many countries. On average, agriculture accounts for $7 \%$ of total export of developed countries, $6 \%$ of total export of developing countries and $4.5 \%$ of export of countries in transition. In case of individual countries, particularly developing countries, agricultural export accounts for more than $60 \%$ of total export. 
Table 1. Significance of agriculture in particular regions (\%)

\begin{tabular}{|l|r|r|r|r|}
\hline \multirow{2}{*}{ Region } & \multicolumn{1}{|c|}{$\begin{array}{c}\text { Share of } \\
\text { agricultural } \\
\text { products export in } \\
\text { total export }\end{array}$} & $\begin{array}{l}\text { Share of agriculture } \\
\text { employment in total } \\
\text { employment }\end{array}$ & $\begin{array}{c}\text { Share of value } \\
\text { added of } \\
\text { agriculture in } \\
\text { GDP }\end{array}$ & $\begin{array}{c}\text { Share of rural } \\
\text { population in } \\
\text { total population }\end{array}$ \\
\cline { 2 - 6 } & $\mathbf{2 0 0 2 - 2 0 0 6}$ & $\mathbf{2 0 0 2 - 2 0 0 6}$ & $\mathbf{2 0 0 3 - 2 0 0 7}$ & $\mathbf{2 0 0 3 - 2 0 0 7}$ \\
\hline World & 6.5 & 30.8 & 3.0 & 51.1 \\
\hline Developed countries & 6.9 & 4.4 & 1.6 & 24.7 \\
\hline Developing countries & 5.9 & 40.0 & 10.2 & 57.3 \\
\hline South-East Europe and CIS & 4.5 & 17.5 & 6.9 & 36.8 \\
\hline South-East Europe & 13.4 & 25.8 & 10.7 & 47.8 \\
\hline CIS & 3.9 & 17.0 & 6.6 & 36.0 \\
\hline
\end{tabular}

Source: UNCTAD (2009): World Investment Report 2009, New York and Geneva, p. 101.

Agricultural products belong to the category of primary products, which has been highly ranked in the world trade for a long time and which had a dominant place in the structure of the world commodity trade during the $19^{\text {th }}$ and the beginning of the $20^{\text {th }}$ century. A significant change occurred after the World War II, when the share of this category of products in the world commodity export was reduced to less than a half, more precisely from $57 \%$ in 1950 to only $22 \%$ in 2000 , primarily due to a long-term price drop tendency and rapid growth of industrial products export (Kovačević, 2003). During the $20^{\text {th }}$ century, the most significant change in the structure of international trade occurred, which was reflected in the fact that agricultural products no longer had the most significant role in the structure of international trade that they used to have in the first half of this century. In relation to the other two categories of products, mining and industrial products, agricultural production has had the slowest growth, which has directly influenced the slow growth of these products export and reduction of their share in the world trade. The share of agricultural products in the world commodity export in 1995 was $11.7 \%$, and in 1999 it was 9.9\% (WTO, 2004).

Table 2. World commodity export per main groups of products (billion USD and \%)

\begin{tabular}{|c|c|c|c|}
\hline Indicator & $\begin{array}{c}\text { Agricultural } \\
\text { products }\end{array}$ & $\begin{array}{c}\text { Fuels and mining } \\
\text { products }\end{array}$ & Manufactures \\
\hline Value (2009) & 1169 & 2263 & 8355 \\
\hline Share in world commodity trade (2009) & 9.6 & 18.6 & 68.6 \\
\hline Annual percentage change & & & \\
\hline $1980-85$ & -2 & -5 & 2 \\
\hline $1985-90$ & 9 & 3 & 15 \\
\hline $1990-95$ & 7 & 2 & 9 \\
\hline $1995-00$ & -1 & 10 & 5 \\
\hline 2000-09 & 9 & 11 & 7 \\
\hline 2007 & 20 & 15 & 15 \\
\hline 2008 & 18 & 33 & 10 \\
\hline 2009 & -13 & -36 & -20 \\
\hline 2010 & 8 & 5.5 & 18.5 \\
\hline 2011 & 4 & 1.5 & 6.5 \\
\hline
\end{tabular}

Source: WTO (2010): International Trade Statistics 2010, Geneva, p. 43 and WTO (2012): International Trade Statistics 2012, Geneva, p. 21. 
In the first decade of the 21st century, the value of agricultural products export was increasing continuously and in 2009 it more than doubled its value in relation to the period nine years ago, reaching 1,169 billion USD (Table 2). This was influenced by the increase of agricultural products prices after 2004. While the share of agricultural products in the world commodity export had continuously been decreasing until 2006 (from $9.9 \%$ in 1999 to $8.0 \%$ in 2006), after that it started increasing (from $8.3 \%$ in 2007 (WTO, 2007) to $9.6 \%$ in 2009), (Table 2). This was assisted by high growth rates of agricultural products export, considering that average growth rate for the period 2000-2009 was 9\%, while the annual percentage change only in 2007 was $20 \%$ and it was $5 \%$ higher than the annual percentage change for fuels and mining products and industrial products (Table 2). One could say that the end of the first decade of the $21^{\text {st }}$ century has brought about certain stabilization, as well as increase of the world agricultural products trade. Furthermore, in the recent period of the global financial crisis, total trade in agricultural products in the world has shown the highest resistance, having the smallest drop in relation to other two groups of products: fuels and mining products and particularly industrial products whose trade had the highest drop (WTO, 2010). The total world export of agricultural products has also had the smallest drop in relation to export drop of the other two product groups (Table 2). World export of agricultural products dropped by $13 \%$ in 2009 , which is a $7 \%$ smaller drop in relation to the drop of fuels and mining products export and a $12 \%$ smaller drop in relation to the drop of industrial products export. In 2010 and 2011, agricultural export recovered; it achieved positive growth rates of $8 \%$ in 2010 and 4\% in 2011, thus significantly exceeding the growth of fuel and mining products export, but still lagging behind the exports of manufactures.

\section{FDI as a source of financing}

The main feature of foreign direct investments is that capital owner retains full control over the invested capital, makes a decision on the use of capital and assumes total risk of using that capital (Stojadinović Jovanović, 2008). In order to define the term and characteristics of foreign direct investments, we will point to the definitions that were given and are used by particular international organizations that perform statistic monitoring and publishing of data on foreign direct investments on the level of countries, regions and the world.

According to the International Monetary Fund (IMF, 1993), a direct investment is a type of international investment undertaken by the enterprise - resident of one country (Direct Investor) with the aim of establishing a lasting interest in the enterprise - resident of a country different from the investor's country (Direct Investment Enterprise). A lasting interest implies the existence of a long-term relationship between the direct investor and the enterprise and a significant level of the direct investor's influence on managing the direct investment enterprise. A direct investment also includes initial transaction between two enterprises and all the following capital transactions between them and associated enterprises, both incorporated and unincorporated. Direct investor can be an individual, incorporated or unincorporated public or private enterprise, government, group of related individuals, or group of related incorporated and/or unincorporated enterprises that own the direct investment enterprise (i.e. subsidiary, associated company or a branch office) which operates in the country different from the country (countries) in which a foreign direct investor (foreign direct investors) is a resident. Direct 
investment enterprise is incorporated or unincorporated enterprise to which a foreign direct investor gives a direct investment. Criteria for the existence of a Direct Investment Relationship is that the enterprise - resident of one country (foreign investor) owns $10 \%$ or more of ordinary shares or voting power in an incorporated or an unincorporated enterprise that is the resident of another country (direct investment enterprise). The direct investment enterprises that are believed to be in direct investment relation with the direct investor are also considered to be in direct investment relations with each other.

According to OECD (1996), a foreign direct investment reflects the aim of establishing a lasting interest of the enterprise - resident of one country (direct investor) in the enterprise - resident of another country (direct investment enterprise). A lasting interest implies the existence of a long-term relationship between the direct investor and the enterprise and a significant influence on enterprise management. Definition provided by OECD is entirely consistent with the definition of IMF, regarding the defining of the very term "direct investment" and all other closely related terms: Direct Investor, Direct Investment Enterprise, Lasting Interest and Long-term Relationship between enterprises, as well as criteria for the existence of a direct investment relationship of 10\% (effective voting right in management, acquired through ownership of at least $10 \%$, which means that the direct investor can influence or take part in enterprise management; it is not obligatory that a foreign investor has absolute control). According to the World Bank (2004), foreign direct investment consists of net investment inflows made in order to accomplish a lasting interest in management (10\% or more of voting right) of an enterprise that operates in the country different from the investor's country. It includes equity, reinvested wages, the second longterm capital and short-term capital, as presented by the balance of payments.

According to UNCTAD (2004), foreign direct investment is defined as the investment that includes a long-term relationship and reflects a lasting interest and control by the enterprise - resident of one country (foreign direct investor or parent enterprise) in the enterprise that is the resident of a country other than that of a foreign direct investor (foreign direct investment enterprise, foreign subsidiary i.e. branch office). Foreign direct investment implies that the investor has significant influence on management of the enterprise that is the resident of another country. This investment also includes initial transaction between two enterprises and all the following transactions between them and between foreign subsidiaries, both incorporated and unincorporated. Foreign direct investments flows include capital that is provided (directly or through other related enterprises) by foreign direct investor to the foreign direct investment enterprise, or capital that foreign direct investor has received from foreign direct investment enterprise. Foreign direct investment consists of three components: equity capital - part of the enterprise that is purchased by a foreign direct investor in a country different from the investor's residence country, reinvested earnings - part of foreign investor's earnings that is not distributed as dividend, but instead serves as profit that is reinvested and intra-company loans - short-term and long-term borrowing of funds between the direct investor (parent company) and subsidiary as well as between subsidiaries themselves. Same as OECD and other international institutions, UNCTAD also uses the $10 \%$ of share in equity as a relevant criterion. 
All the given definitions, although different, have certain common characteristics. In order to be considered as a foreign direct investment, an investment must be made in country other than the investor's country. Then, the investment must be made with the intention of a longterm commitment, i.e. establishment of a long-term relationship and lasting interest between a foreign direct investor and foreign direct investment enterprise. In addition, it is important that a foreign investor has a significant control and the right to influence enterprise management due to the investment. There is an agreement that the threshold of at least $10 \%$ of property or more is needed for a foreign investor to become qualified as a foreign direct investor (Stojadinović Jovanović, 2008).

Foreign direct investments in agriculture can be achieved in different manners and through different activities. Investors from abroad can be directly included in agricultural production by founding a wholly owned subsidiary. In addition, they can be buyers of agricultural products or input suppliers in agriculture. Furthermore, they can be distributors of agricultural products or can be included in jobs such as processing, trade or marketing. Foreign direct investors' share in agriculture of the country can also be accomplished through activities such as food processing, wholesale and retail, as well as various inputs supply (equipment, fertilizers, seed). Bearing in mind these different forms of foreign capital and foreign investors' share in agricultural production of a country and many other activities related to it, we can observe the significance of each form of foreign participation in agriculture. For individual countries' agriculture these are the reasons why direct investments from abroad, as one form of foreign share in agriculture, could be extremely significant and of great influence (Figure 1).

Figure 1. Types of impacts on host country's agriculture

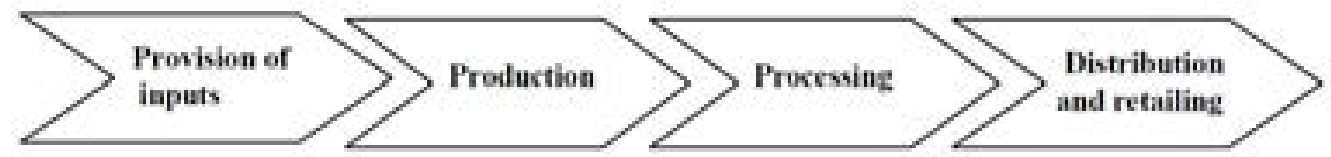

\begin{tabular}{|c|c|c|c|}
\hline $\begin{array}{l}\text { Producing inputs and } \\
\text { supplying them to } \\
\text { farmers }\end{array}$ & $\begin{array}{l}\text { Operating plantations or contract } \\
\text { farming schemes }\end{array}$ & $\begin{array}{l}\text { Procuring farm } \\
\text { produce and } \\
\text { processing }\end{array}$ & $\begin{array}{l}\text { Procuring processed } \\
\text { products and } \\
\text { distributing }\end{array}$ \\
\hline & $\begin{array}{l}\text { Increasing investment and providing } \\
\text { finance to farmers; crowding in or out } \\
\text { domestic investment }\end{array}$ & \multicolumn{2}{|c|}{$\begin{array}{l}\text { Promoting the commercialization and } \\
\text { modernization of agriculture }\end{array}$} \\
\hline $\begin{array}{l}\text { Transferring technology } \\
\text { through provision of } \\
\text { inputs }\end{array}$ & $\begin{array}{c}\text { Transferring technology by introducing } \\
\text { new inputs and methods, and } \\
\text { undertaking R\&D }\end{array}$ & \multicolumn{2}{|c|}{$\begin{array}{c}\text { Involving some farmers in the value chain and } \\
\text { providing assistance to them, but marginalizing } \\
\text { others }\end{array}$} \\
\hline $\begin{array}{l}\text { Influencing the } \\
\text { agricultural innovation }\end{array}$ & $\begin{array}{l}\text { Influencing the quantity and quality of } \\
\text { rural employment }\end{array}$ & \multicolumn{2}{|c|}{$\begin{array}{l}\text { Enhancing access to foreign markets and } \\
\text { promoting exports }\end{array}$} \\
\hline & $\begin{array}{l}\text { Linkages within and beyond the } \\
\text { agribusiness value chain, and various } \\
\text { effects on the economy at large }\end{array}$ & \multicolumn{2}{|c|}{$\begin{array}{c}\text { Competitive effects at various stages in the } \\
\text { value chain; abuse of market power by foreign } \\
\text { affiliates }\end{array}$} \\
\hline
\end{tabular}

Source: UNCTAD (2009): World Investment Report 2009, New York and Geneva, p. 134. 
The importance of FDI as a source of agriculture financing results from the fact that FDIs can bring numerous benefits to agriculture of the host country, which reflect in the fact that FDI can:

- contribute to total capital inflows in agriculture;

- increase investment and provide finance to farmers;

- influence investment in infrastructure facilities, such as: transport infrastructure, water supply, electrification etc.;

- transfer technology by introducing new inputs and methods and conducting research and development activities;

- influence the agricultural innovation system;

- intensify the commercialization and modernization of agriculture;

- contribute to diffusion of international standards respecting quality and safety of agricultural products;

- enhance access to foreign markets and promoting of exports;

- bring the different kind of linkages: linkages with suppliers (backward linkages), linkages with customers (forward linkages) and with others, producing various effects on the business activities.

These benefits and potential positive impacts of FDI on agriculture are the reasons why financing of agriculture through FDI and inflow of this form of foreign capital into countries' agriculture is of great importance.

\section{FDI in agriculture financing}

As much as agriculture is significant in the world economy and trade, its financing through FDI is not so significant. It can be observed that in global flows of FDI, agriculture is not that important. In the first decade of the $21^{\text {st }}$ century, in spite of significant increase of global flows of FDI, the inflows of FDI in agriculture could be estimated as rather modest. With the growth tendency after 1999, FDI inflows in agriculture and food and beverage production in 2007 reached 60 billion USD (Figure 2 ), jointly making up $3 \%$ of total world FDI inflows in that year. Within this group, there were significant differences between the two categories: agriculture ${ }^{4}$, on one hand, and food and beverages, on the other hand, from the aspect of foreign investments inflow value. Between 1989 and 1991, FDI world flows in agriculture were below 1 billion per year, while in case of food and beverages they exceeded 7 billion USD. This trend of significantly higher foreign investments in subsector of food and beverages production has continued. Regarding agriculture, in the period 2005-2007, FDI world inflows exceeded the value of 3 billion USD per year.

4 including forestry and fishing.

EP 2014 (61) 2 (455-469) 
Figure 2. World: FDI inflows in agriculture, forestry and fishing, food and beverages (billions of USD)

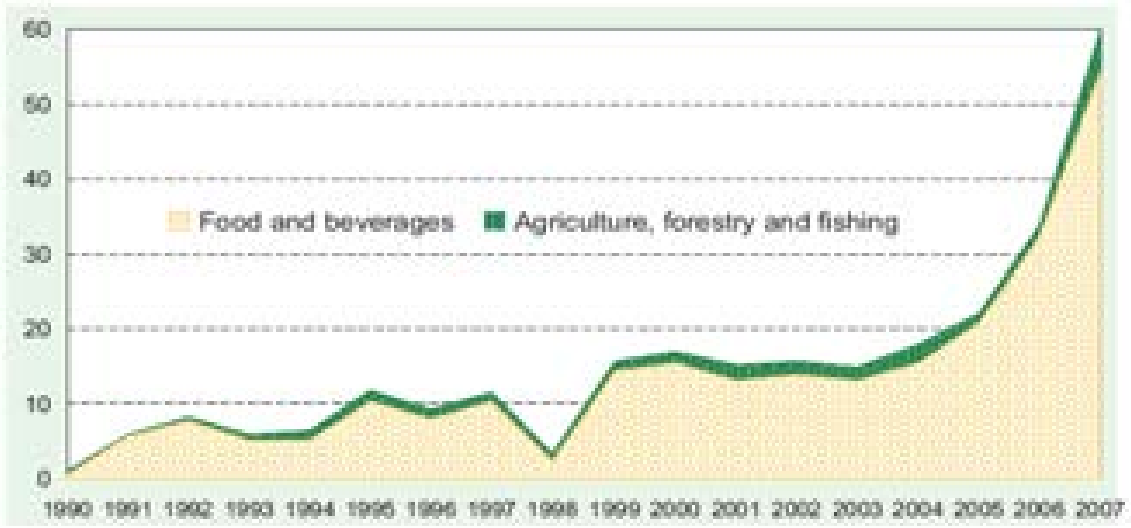

Source: adopted from UNCTAD (2009): World Investment Report 2009, UN, New York and Geneva, p. 111. In the following periods, 2007-2009 and 2008-2010, there was a significant increase of absolute amounts of FDI inflows in agriculture, which in fact doubled, exceeding 6 billion USD (Table 3). In the period 2009-2011, FDI inflows in agriculture maintained the same level as in 2008-2010, meaning that they were twice higher than in the period 2005-2007 and more than ten times higher than two decades ago. This increase was the consequence of restored significance of agriculture, at both national and international level, as well as increased significance of a number of issues in world economy relating to 2008 food crisis, the need to meet the targets of millennium developmental goals and the rise of biofuel production. However, despite this tendency of growth of FDIs' absolute level in agriculture, they still make up less than $1 \%$ of total world FDI inflow.

Table 3 . Estimated world inward FDI flows, per selected sector and industry (millions of USD)

\begin{tabular}{|l|r|r|r|r|r|r|}
\hline \multicolumn{1}{|c|}{ Indicator } & \multicolumn{1}{|c|}{$\begin{array}{c}\text { 1989- } \\
\text { 1991 }\end{array}$} & $\mathbf{1 9 9 0 - 1 9 9 2}$ & $\mathbf{2 0 0 5 - 2 0 0 7}$ & $\mathbf{2 0 0 7 - 2 0 0 9}$ & $\mathbf{2 0 0 8 - 2 0 1 0}$ & $\mathbf{2 0 0 9 - 2 0 1 1}$ \\
\hline Total (world) & 186549 & 175803 & 1471264 & 1633357 & 1432510 & 1425507 \\
\hline $\begin{array}{l}\text { Agriculture, hunting, } \\
\text { forestry and fishing }\end{array}$ & 623 & 709 & 3328 & 6765 & 6290 & 6280 \\
\hline $\begin{array}{l}\text { Food, beverages and } \\
\text { tobacco }\end{array}$ & 7151 & 7155 & 40545 & 69056 & 70483 & 45739 \\
\hline $\begin{array}{l}\text { Share of agriculture, } \\
\text { hunting, forestry and } \\
\text { fishing in world inward } \\
\text { FDI flows }\end{array}$ & $0.3 \%$ & $0.4 \%$ & $0.2 \%$ & $0.4 \%$ & $0.4 \%$ & $0.4 \%$ \\
\hline
\end{tabular}

Source: Authors' calculations of shares based on UNCTAD (2009). World Investment Report 2009. UN and Geneva, p. 220 and UNCTAD database, Internet, Available at: http://unctad.org/Sections/ dite_dir/docs/WIR12_tab26.xls and http://archive.unctad.org/sections/dite_dir/docs/WIR11_web $\% 20$ tab\% 2026.pdf, Accessed 20/08/2013 and http:/unctad.org/en/Pages/DIAE/World\%20Investment\%20 Report/Annex-Tables.aspx, Annex Table 26, Accessed 30/05/2014. 
If we take a look at the cumulative state, i.e. stock of FDI in the world and agriculture, we will also notice that share of agriculture is very small. Total stock of input FDIs in the world in 2007 was 15,696 billion USD and in agriculture, hunting, forestry and fishing 32 billion USD, which was only $0.2 \%$ of the total stock of FDIs in the world. This implies a drop in significance of agriculture in relation to 1990, when stock of input FDI in agriculture was 8 billion USD, which was $0.4 \%$ of the total world stock of FDI (UNCTAD, 2009). In the following years, 2009 and 2010, stock of FDI in agriculture exceeded 50 billion USD, but without a significant increase of share in the total world stock of FDI (share of $0.3 \%$ was achieved) $)^{5}$. In 2011, inward FDI stock in agriculture reached 59 billion USD, which, although it was an absolute increase, did not result in increment of their share in world FDI stock but in small reduction in its already small share in total world inward FDI stock (on the level of $0.28 \%)^{6}$. On the global level, these data reflect not only insufficient attractiveness of agriculture to foreign investors, but also its declining importance.

On the level of individual countries, share of agriculture in total FDI inflows, in the period 2005-2007 went between below $1 \%$ and $15 \%$. Thereat, it was below $1 \%$ in 17 countries, including Serbia, out of 40 developing countries that were taken into consideration. It was also observed that share of agriculture in total stock of FDI did not exceed $1 \%$ in 21 country out of 40 observed countries (UNCTAD, 2009). This indicates poor financing of agriculture through FDI on both the global level and the level of individual countries, as well as the insufficient attractiveness of this area to foreign capital.

\section{Serbian agricultural trade and financing through FDI}

Agricultural products are of special importance for Serbian economy and its foreign trade exchange. Even in the period of financial crisis in 2008, they have maintained their growth and significant role in the total export of the country. Continuous growth of the total merchandise exports of Serbia that started in 2005, was stopped in 2009, due to financial crisis, so the total export of Serbia in 2009 in absolute amount achieved the value that was below the level of 2007 (Table 4).

Table 4. External Trade Balance of Serbia (millions of USD)

\begin{tabular}{|l|r|r|r|r|r|r|r|}
\hline Indicator & \multicolumn{1}{c|}{$\mathbf{2 0 0 5}$} & \multicolumn{1}{c|}{$\mathbf{2 0 0 6}$} & \multicolumn{1}{c|}{$\mathbf{2 0 0 7}$} & \multicolumn{1}{c|}{$\mathbf{2 0 0 8}$} & \multicolumn{1}{c|}{$\mathbf{2 0 0 9}$} & \multicolumn{1}{c|}{$\mathbf{2 0 1 0}$} & \multicolumn{1}{c|}{2011} \\
\hline $\begin{array}{l}\text { Merchandise } \\
\text { Exports }\end{array}$ & 4482 & 6428 & 8825 & 10974 & 8344 & 9795 & 11779 \\
\hline $\begin{array}{l}\text { Merchandise } \\
\text { Imports }\end{array}$ & 10461 & 13172 & 19164 & 24331 & 15807 & 16470 & 19862 \\
\hline
\end{tabular}

Source: Statistical Office of the Republic of Serbia (2010): Statistical Yearbook 2010. Belgrade, p. 297 and Statistical Office of the Republic of Serbia (2012): Statistical Yearbook 2012. Belgrade, p. 283.

5 Authors' calculations of shares based on UNCTAD database, Internet, Available at: http://unctad. org/Sections/dite_dir/docs/WIR12_tab24.xls and http://archive.unctad.org/sections/dite_dir/docs/ WIR11_web\%20tab\%2024.pdf, Accessed 20/08/2013.

6 Authors' calculations of share based on UNCTAD database, Internet, Available at: http://unctad. org/en/Pages/DIAE/World\%20Investment\%20Report/Annex-Tables.aspx, Annex Table 24, Accessed 30/05/2014.

EP 2014 (61) 2 (455-469) 
And while the total export of Serbia was decreasing after 2008, achieving lower values both in 2009 and 2010 in relation to 2008, the export of agricultural products from Serbia was increasing continuously (Table 5). Over the last ten years, Serbia has significantly increased the value of export of agricultural products, the greatest share of which was achieved by agricultural products from the food group. Food export has accounted for more than $20 \%$ of total merchandise export of the country. Data in the following Table 5 show a continuous growth of the value of export of agricultural products from Serbia, especially food whose value of the export in 2011 reached 2,630 million USD (WTO, 2012).

Table 5. Export of agricultural products and food from Serbia (millions of USD)

\begin{tabular}{|l|c|c|c|c|c|}
\hline & $\mathbf{2 0 0 0}$ & $\mathbf{2 0 0 7}$ & $\mathbf{2 0 0 8}$ & $\mathbf{2 0 0 9}$ & $\mathbf{2 0 1 0}$ \\
\hline Exports of agricultural products & 389 & 1822 & 2100 & 2031 & 2359 \\
\hline Exports of food & 290 & 1642 & 1906 & 1906 & 2189 \\
\hline
\end{tabular}

Note: 2000 data refer to Serbia and Montenegro.

Source: WTO (2010): International Trade Statistics 2010, Geneva, p. 52 and 57, and WTO (2011): International Trade Statistics 2011, Geneva, p. 68 and 73.

Measures and activities undertaken in the previous period had a significant influence on such changes. Opening of EU market for agricultural and food products from Serbia, owing to Autonomous Trade Preferences from 2000, as well as numerous bilateral trade agreements with countries from the region, later embodied in CEFTA agreement, have created conditions for the increase of food export from Serbia and transformation of Serbia into a food net-exporter country. Serbia got this status for the first time in 2005, when it created a surplus of more than 150 million USD (Ministry of agriculture, forestry and water management of Republic of Serbia, 2010).

In the following period, by achieving the value of agricultural products export of more than 2 billion USD, Serbia created a significant surplus in the external trade of these products. Thus, with the achieved value of the agricultural products export of 2.03 billion USD, during 2009, Serbia created the surplus of more than 630 million USD (Zekić et al, 2010), which was the highest surplus ever achieved by Serbia in agricultural trade. In addition, the fact that share of agricultural products in total export of the country has increased to over $20 \%$ also demonstrates the significance of these products for the overall economy and foreign trade exchange of the country.

From the aspect of Serbian agriculture financing through foreign direct investments, it can be observed, however, that out of total inflow of investments from abroad, a small part goes to agriculture. Inflows of foreign capital into Serbian economy are not directed to all sectors of economy equally. Directing of foreign capital, used for financing particular sectors of Serbian economy, has suffered significant changes in the first decade of the $21^{\text {st }}$ century (Stojadinović Jovanović, 2012). The sector structure of Serbian FDI inflows points out that the majority of FDI goes to financial intermediation, traffic and telecommunications, manufacturing, trade and real-estate business (NBS, 2013). FDI inflows into agriculture and food and beverages production industry are very modest. Furthermore, similar to the worldwide tendency, FDI 
inflows in agriculture are significantly smaller than FDI inflows in food industry. Foreign investors are much more attracted to the production of food and beverages, with the annual FDI inflow value that, in some years, was up to ten times higher compared with agriculture sector (Table 6). In the period 2004-2012, agriculture sector accounted for $0.2 \%$ to $1.6 \%$ of total FDI inflow in Serbia, while food industry accounted for $0.79 \%$ to $13.45 \%$. A very small share of agriculture indicates lack of attractiveness of this sector in Serbia and lack of interest of foreign investors for investing in it.

Table 6. FDI inflows in agriculture and food industry of Serbia (thousands of USD)

\begin{tabular}{|c|r|r|r|r|r|}
\hline \multirow{2}{*}{ Year } & \multirow{2}{*}{$\begin{array}{c}\text { Total FDI in } \\
\text { Serbia }\end{array}$} & \multicolumn{2}{|c|}{ Agriculture } & \multicolumn{2}{c|}{$\begin{array}{c}\text { Production of food products and } \\
\text { beverages }\end{array}$} \\
\cline { 3 - 6 } & & FDI & \multicolumn{1}{c|}{$\begin{array}{c}\text { Share in total } \\
\text { FDI (\%) }\end{array}$} & \multicolumn{1}{c|}{ FDI } & $\begin{array}{c}\text { Share in total } \\
\text { FDI (\%) }\end{array}$ \\
\hline 2004 & 987239 & 9449 & 0.95 & 97759 & 9.90 \\
\hline 2005 & 1616438 & 11578 & 0.72 & 65132 & 4.03 \\
\hline 2006 & 5425147 & 11345 & 0.21 & 78370 & 3.44 \\
\hline 2007 & 3921220 & 20970 & 0.53 & 133688 & 4.11 \\
\hline 2008 & 3602980 & 57908 & 1.61 & 147944 & 43.45 \\
\hline 2009 & 2497697 & 29288 & 1.17 & 335974 & 4.68 \\
\hline 2010 & 1519490 & 14556 & 0.96 & 71167 & 2.74 \\
\hline 2011 & 3125274 & 13675 & 0.44 & 85687 & 0.79 \\
\hline 2012 & 355287 & 1030 & 0.29 & 2807 & \\
\hline
\end{tabular}

Source: Authors' calculation based on the data of the National Bank of Serbia, Internet, Available at: www.nbs.rs, Foreign investments by industries, Accessed 25/08/2013.

Similarly to the worldwide tendency, in Serbia, as well, growth of absolute values of FDI inflows in agriculture did not bring the increase of their share in total FDI inflows in the country. Before 2008, i.e. before the world financial crisis, absolute amounts of FDI inflows had been increasing, but their share had not exceeded 2\% of total FDI inflows in Serbia. After that, FDI inflows in agriculture significantly declined and in 2010 they accounted for less than $1 \%$ of total FDI inflows in Serbia, and in 2011 less than $0.5 \%$. With significant decline of total FDI in Serbia in 2012, there was also a significant decrease of FDI in agriculture on the level of only $0.3 \%$ of total FDI inflow in the country. In the observed period, the lower share existed only in 2006.

Foreign direct investment inflows in agriculture reached their maximal value in 2008, and they amounted to 58 million USD, i.e. 336 million USD in food industry in 2009. After that, they suffered a drastic decline. These inflows in agriculture of Serbia were reduced for more than a half in 2010 and they kept declining in 2011, while the inflow of foreign direct investments in food industry was almost five times smaller in 2010 in relation to 2009, after which there was a mild increase in 2011, but that level was still rather low and four times smaller than in 2009. This resulted in the fact that in 2011, in relation to 2010, share of agriculture as well as food industry in total inflows of foreign direct investments into the country was halved, still demonstrating rather small or even diminished attractiveness of this sector for foreign investors and inflows of direct investments from abroad. 
Although the agricultural production is of vital importance for economic development and growth of Serbia, FDIs directed to agriculture of Serbia are rather modest. Most FDIs are directed to services sector and they have no significant effect on agricultural production and export of agricultural products of Serbia. All this was also affected by the fact that for a long time Serbia has not had a clearly defined strategy for foreign direct investments; therefore the encouragement of FDI inflow in agriculture did not get any special attention. Strategy of stimulation and development of foreign investments (Vlada Republike Srbije, 2006). of the Government of the Republic of Serbia represents the most significant document in this field; however, it also failed to give sufficient attention to directing foreign investments towards agriculture in the sense of providing detailed and accurate measures and instruments for proper action. In the draft of the National programme for agriculture of Serbia (Ministry of agriculture, forestry and water management of Republic of Serbia, 2010), increase of investments in agricultural and rural sector was foreseen as one of specific priority goals for the period 2010-2013, but no actual steps for carrying it into effect were given.

\section{Conclusion}

Comparative analysis of agricultural trade on the global level, as well as on the level of Serbia, has shown that agriculture has a significant place both in the overall world trade and in trade of individual countries, as well as in Serbia. On the other hand, despite its significance in the overall, global economy and trade, as well as on the national level of individual countries, agriculture is not sufficiently attractive for foreign investments, which is why it is characterized by low FDI inflows. Insufficient attractiveness for direct investments from abroad is the observed characteristic of agriculture on the global level as well as on the national level of individual countries. Low level of FDI in agriculture, both on the global level and on the level of Serbia, points to the fact that direct investments are not sufficiently present in agriculture, and also that in this way possible positive impacts that this inflow could have on agriculture are not used either.

The paper has shown that FDI can contribute to agriculture in different ways, indicating the benefits and potential positive impacts on agriculture. However, small attractiveness of agriculture for FDI inflows and the small volumes of FDI in agriculture lead to the conclusion that these resources and their potentials have not been exploited. By recognizing potential benefits and taking measures for attracting and increasing investments in agriculture, possibilities for achieving potential positive effects, which this investment inflow in agriculture could bring, would be created.

Therefore, one of the important aims of national economic and FDI policies should be improvement of participation of FDI in agriculture and food industry. In order to do this, certain proposals may be made:

- regarding specific features of agriculture and agricultural production, national FDI policy should include a special part that would deal with FDI in agriculture in order to give special attention to this kind of FDI; 
- situation in national agriculture and essential agricultural issues such as: agrarian structure and the level of agricultural producers' organisation, the level of regulation of agricultural market and the role of state, the level of rural development as well as the level of competitiveness should be given highlighted importance in order not only to improve the situation in agriculture, but also to improve attractiveness of agriculture for foreign investors;

- regarding the specificity of agriculture in the sense of dependence on nature and subordination to natural conditions, the issue of insurance - the possibility and conditions under which it can be made - comes to the fore;

- as in other areas, national FDI polices should also include some kind of (fiscal, financial and other) incentives for FDI in agriculture, in order to attract foreign investors in this sector;

- improvement of FDI participation in agriculture and food industry can not be achieved in isolation; instead, it must be done in the context of the improvement of total macroeconomic environment of national economy - its macroeconomic indicators and investment climate indicators.

\section{References}

1. International Monetary Fund (1993): IMF's Balance of Payments Statistics Manual, IMF, fifth edition, Washington DC, USA.

2. Kovačević, M. (2003): Međunarodna trgovina, Ekonomski fakultet, Beograd.

3. Ministarstvo poljoprivrede, šumarstva i vodoprivrede Republike Srbije (2010): Nacionalni program poljoprivrede Srbije 2010-2013 - Nacrt, Beograd, Srbija.

4. National Bank of Serbia, Foreign investments by industries, available at: www.nbs.rs, Accessed 25/08/2013.

5. OECD (1996): OECD's Benchmark Definition of Foreign Direct Investment, The third edition, Paris, France.

6. Statistical Office of the Republic of Serbia (2010): Statistical Yearbook 2010, Belgrade.

7. Statistical Office of the Republic of Serbia (2012): Statistical Yearbook 2012, Belgrade.

8. Stojadinović Jovanović, S. (2008): Transnacionalizacija međunarodne trgovine, Prometej, Beograd.

9. Stojadinović Jovanović, S. (2012): Aktuelna kretanja u finansiranju privrede Srbije prilivima stranog kapitala, zbornik radova: Aktuelna kretanja u evropskoj i svetskoj privredi: implikacije na Srbiju, NDES sa Akademijom ekonomskih nauka, Ekonomski fakultet u Beogradu i Ekonomski fakultet u Kragujevcu, 19. oktobar 2012, Kragujevac, pp. 171-179.

10. UNCTAD (2004): World Investment Report 2004, UN, New York and Geneva.

11. UNCTAD (2009): World Investment Report 2009, UN, New York and Geneva.

12. UNCTAD database, Available at: $\underline{\text { http://unctad.org/en/Pages/DIAE/World } \% 20}$

EP 2014 (61) 2 (455-469) 
Investment\%20Report/Annex-Tables.aspx, Annex Table 26, Accessed 30/05/2014.

13.UNCTAD database, Available at: $\mathrm{http}: / /$ unctad.org/en/Pages/DIAE/World $\% 20$ Investment\%20Report/Annex-Tables.aspx, Annex Table 24, Accessed 30/05/2014.

14.UNCTAD database, Available at: http://unctad.org/Sections/dite_dir/docs/WIR12 tab26.xls and http://archive.unctad.org/sections/dite dir/docs/WIR11_web\%20tab\%20 26.pdf, Accessed 20/08/2013.

15.UNCTAD database, Available at: http://unctad.org/Sections/dite_dir/docs/WIR12 tab24.xls and http://archive.unctad.org/sections/dite dir/docs/WIR11_web\%20tab\%20 24.pdf, Accessed 20/08/2013.

16. Vlada Republike Srbije (2006): Strategija podsticanja i razvoja stranih ulaganja. Beograd, mart 2006, Srbija.

17. World Bank (2004): World Development Indicators 2004, The International Bank for Reconstruction and Development/The World Bank, Washington DC, USA.

18. WTO (2004): International Trade Statistics 2004, Geneva.

19. WTO (2007): International Trade Statistics 2007, Geneva.

20. WTO (2010): International Trade Statistics 2010, Geneva.

21. WTO (2011): International Trade Statistics 2011, Geneva.

22. WTO (2012): International Trade Statistics 2012, Geneva.

23.Zekić, S., Tošin, M., Kresoja, M. (2010): Spoljnotrgovinska razmena poljoprivrednoprehrambenih proizvoda Srbije, u Ševarlić M., Tomić D. (ur.) Agroprivreda Srbije i evropske integracije, Beograd: DAES, Tematski zbornik, str. 95-102, available at: http:// portal.zzbaco.com/mojo baco/Data/Sites/1/docs/EvropInt/05.pdf, Accessed 21/09/2013. 


\title{
TRGOVINA POLJOPRIVREDNIM PROIZVODIMA I FINANSIRANJE PUTEM SDI
}

\author{
David Jovovičc , Sandra Stojadinović Jovanovič ${ }^{8}$, Boban Dašič ${ }^{9}$
}

\begin{abstract}
Rezime
Uloga i značaj poljoprivrednih proizvoda su se menjali tokom vremena, kako u svetskoj trgovini tako $i$ u globalnim tokovima stranih direktnih investicija. Predmet analize u radu će biti upravo ova dva aspekta, trgovina poljoprivrednim proizvodima $i$ finansiranje poljoprivrede stranim direktnim investicijama. Strane direktne investicije mogu doprineti odvijanju poljoprivrede na različite načine, donoseći određene koristi $i$ potencijalne pozitivne uticaje. Stoga će rad analizirati tokove i obime stranih direktnih investicija u poljoprivredi ukazujući da li su potencijali za ove uticaje iskorišćeni. Cilj rada je da istraži tokove trgovine poljoprivrednim proizvodima i tokove i obime stranih direktnih investicija kojima se poljoprivreda finansira kako bi utvrdili kako i u kojoj meri oni doprinose odvijanju poljoprivrede.
\end{abstract}

Ključne reči: poljoprivreda, strane direktne investicije, trgovina, Srbija.

7 Dr David Jovović, Vanredni profesor, Poljoprivredni fakultet Univerziteta u Prištini - Kosovska Mitrovica, 38219 Lešak, Srbija, Telefon: + 38164 5999421, E-mail: jovovicdavid@gmail.com

8 Dr Sandra Stojadinović Jovanović, Docent, Ekonomski fakultet Univerziteta u Beogradu, Kamenička 6, 11000 Beograd, Srbija, Telefon: + 381113021 102, E-mail: sandra@ekof.bg.ac.rs

9 Dr Boban Dašić, Visoka ekonomska škola strukovnih studija Peć - Leposavić, 24. novembra bb, 38218 Leposavić, Srbija, Telefon: + 38165 6265211, E-mail: bobandasickg@gmail.com

EP 2014 (61) 2 (455-469) 